\title{
Anti-La Antibody
}

National Cancer Institute

\section{Source}

National Cancer Institute. Anti-La Antibody. NCI Thesaurus. Code C121323.

An antinuclear antibody directed against a $47 \mathrm{kDa}$ RNA-binding protein in the nucleus.

They can be associated with Sjog ren syndrome and system lupus erythematosus.

Maternal anti-La antibody positivity can be associated with neonatal lupus. 